University of Florida Levin College of Law

UF Law Scholarship Repository

\title{
A Socio-Economic Approach to Antitrust: Unpacking Competition, Consumer Surplus, and Allocative Efficiency
}

Jeffrey L. Harrison

University of Florida Levin College of Law, harrisonj@law.ufl.edu

Follow this and additional works at: https://scholarship.law.ufl.edu/facultypub

Part of the Antitrust and Trade Regulation Commons

\section{Recommended Citation}

Jeffrey L. Harrison, A Socioeconomic Approach to Antitrust: Unpacking Competition, Consumer Surplus, and Allocative Efficiency, 49 Akron L. Rev. 409 (2016), available at

This Article is brought to you for free and open access by the Faculty Scholarship at UF Law Scholarship Repository. It has been accepted for inclusion in UF Law Faculty Publications by an authorized administrator of UF Law Scholarship Repository. For more information, please contact kaleita@law.ufl.edu. 


\title{
A SOCIO-ECONOMIC APProACh To ANTITRUST: UNPACKING COMPETITION, CONSUMER SURPLUS, AND Allocative EfFiciency
}

\author{
Jeffrey L. Harrison*
}

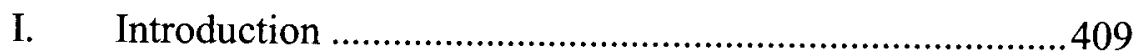

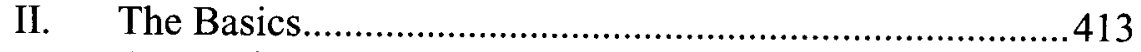

A. Nominal Antitrust Goals.......................................... 413

B. The Missing Elements.....................................................417

III. The "Economics" of Today's Antitrust Policy..................421

IV. A Role for Socio-economics?............................................425

A. Socio-economic Portals: Consumer Surplus .................427

B. Socio-economic Portals: Allocative Efficiency .............430

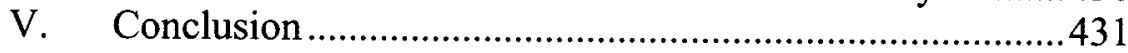

\section{INTRODUCTION}

Socio-economics requires constant questioning. The core notion of examining all policies, laws, and values from any relevant perspective is something that is too often lacking in legal scholarship. American antitrust law may be particularly representative of intellectual inertia. ${ }^{1}$ For over $\mathbf{4 0}$ years, it has teetered between strict reliance on neoclassical economics and a deeply conservative political philosophy characterized, at its most benign, by a distrust of government. This does not necessarily mean that the socio-economic-based questioning results in easily stated or formulated prescriptions for change. Indeed, another important facet of socio-economics is that it is not agenda driven.

Questioning antitrust policy is made convenient by the nature of laws governing antitrust. They are no more than general guidelines that permit a common law approach to antitrust that has gone in different

\footnotetext{
* Professor of Law, University of Florida

1. Some have characterized scholarship in the area as comparable to refining a Model $\mathrm{T}$ automobile.
} 
directions. ${ }^{2}$ These laws were open to interpretation and application in light of all relevant information. ${ }^{3}$ For example, Section 1 of the Sherman Act prohibits agreements that restrain trade. ${ }^{4}$ Virtually every contract restrains trade, and courts had to interpret the Act to allow for everyday transactions that should not be viewed as illegal. ${ }^{5}$ Similarly, Section 2 of the Sherman Act prohibits monopolization and attempts to monopolize. ${ }^{6}$ Even here it was not clear whether the law prohibited the existence of monopolies or something else. ${ }^{7}$ Consequently, a socio-economic ${ }^{8}$ approach could have evolved from current statutes, and, thus, this Article assumes the status quo with respect to the statutory framework.

First, to provide some background information, much of the current discussion about revising antitrust is framed in terms of fairness or morality. ${ }^{9}$ Those terms can have both consequentialist and deontological

2. Interestingly, the one portion of the antitrust laws that is not expressed in general terms is the Robinson-Patman Act, 15 U.S.C. 13, which provides fairly clear guidance with respect to interpretation and has been redefined by the current Supreme Court. See generally E. THOMAS SULLIVAN \& JEFFREY L. HARRISON, UNDERSTANDING ANTTRUUST AND ITS ECONOMIC IMPLICATIONS, Chapter 8, (6th ed. 2013).

3. For a fuller discussion of what socio-economics involves, see, Robert Ashford, SocioEconomics: What is its Place in Law Practice?, 1997 WIS. L. REV. 611 (1997); Jeffrey L. Harrison, Law and Socioeconomics, 49 J. LEGAL EDUC. 224, 231 (1999).

4. "Every contract, combination in the form of trust or otherwise, or conspiracy, in restraint of trade or commerce among the several States, or with foreign nations, is declared to be illegal. Every person who shall make any contract or engage in any combination or conspiracy hereby declared to be illegal shall be deemed guilty of a felony, and, on conviction thereof, shall be punished by fine not exceeding $\$ 100,000,000$ if a corporation, or, if any other person, $\$ 1,000,000$, or by imprisonment not exceeding 10 years, or by both said punishments, in the discretion of the court." 15 U.S.C. $\$ 1$ (1890).

5. See SUllivan \& HARRISON, supra note $2, \S 2.01$

6. "Every person who shall monopolize, or attempt to monopolize, or combine or conspire with any other person or persons, to monopolize any part of the trade or commerce among the several States, or with foreign nations, shall be deemed guilty of a felony, and, on conviction thereof, shall be punished by fine not exceeding $\$ 100,000,000$ if a corporation, or, if any other person, $\$ 1,000,000$, or by imprisonment not exceeding 10 years, or by both said punishments, in the discretion of the court." 15 U.S.C. $\$ 2$ (1890).

7. The issue was dealt with most directly in U.S. v. Aluminum Co. of America, 148 F.2d 416, 427-29 (2d Cir. 1945).

8 . For the uninitiated, here is a brief but concise description of socio-economics. "Socioeconomists thus conceive of their approach as both a positive and a normative science. Like other social sciences, socio-economics is dedicated to empirical testing. It respects both inductive and deductive reasoning. It respects the importance of falsifiability, consistency, predictive power, and explanatory power. But it also openly recognizes the policy relevance of teaching and research and seeks to be aware of its normative implications rather than maintaining the mantle of an exclusively positive science. Although it sees questions of value inextricably connected with individual and group economic choices, socio-economics does not commit to any one paradigm or ideological position. Like a good lawyer, a socio-economist is sensitive to the foundation upon which reasoning is based, and upon which evidence is gathered and analyzed." See Ashford, supra note 3, at 613 .

9. See infra notes 10-19 and accompanying text. 
connotations. Here, I try to stick to a consequentialist perspective. There may be "rights" and "wrongs" in terms of antitrust, but sometimes those claims are too easy to make, and it is unlikely there can be agreement. I realize, of course, that even the decision not to go down the normative path is itself a normative decision. Nevertheless, I have tried to limit this commentary to things about which people can disagree without relying — as much as current antitrust policy does—on faith.

Second, it is not part of the socio-economics agenda to change antitrust law. Indeed the beauty of the socio-economic approach is that it starts with no agenda other than to bring together all relevant information that bears on an issue. Thus, a socio-economic approach can appeal to anyone who is open to falsification and who will entertain the possibility that the status quo is not the ideal. In fact, for those who think socio-economics will open up antitrust to a greater and less irrational application, the opposite may be true. Socio-economics may firmly support the status quo. Since neoclassical models are ultimately about values, some aspects of socio-economics are designed to make values more visible than the current market-based models.

Finally, I want to be clear that I am not writing on a clean slate. The unease with today's antitrust policy, although perhaps suppressed by the preferences of law review editors for convention, ${ }^{10}$ has existed for decades. Indeed, as far back as 1982, Herb Hovenkamp, now one of the coauthors of the antitrust treatise that has become a staple antitrust source for the Supreme Court, ${ }^{11}$ wrote about the possible need for a broader perspective when it comes to antitrust goals. ${ }^{12}$ Hovenkamp cautioned that, "antitrust policy must come to grips with the fact that people sometimes may be willing to pay higher consumer prices to realize certain values, and that those values cannot always be determined in the voluntary market." 13 Much more recently, Maurice Stucke asks in a provocative article, "Should Competition Policy Promote Happiness?" $\mathrm{He}$ writes, "Political, social, and moral values play as

10. See Jeffrey L. Harrison \& Amy R. Mashburn, Citations, Justifications, and the Troubled State of Legal Scholarship: An Empirical Study, 3 TEX. WESLEYAN L. REV. 45 (2015).

11. A Westlaw search conducted on July 10,2015, found that the names Areeda and Hovenkamp were cited in 15 antitrust cases. It was assumed that this meant a reference to their treatise. P. AREEDA \& H. HOVENKAMP, ANTITRUST LAW: AN ANALYSIS OF ANTITRUST PRINCIPLES AND THEIR APPLICATION (2d ed. 2004). For Richard Posner the number is 10.

12. Herbert Hovenkamp, Distributive Justice and the Antitrust Laws, 51 GEO. WASH. L. REV. 1,1 (1982).

13. Id. at 30 . In the same work it is important to note that Hovenkamp argues that the principal focus of antitrust should be what would occur in voluntary markets. Id. at 31 .

14. Maurice E. Stucke, Should Competition Policy Promote Happiness?, 81 FORDHAM L. REV. 2575, 2575 (2013). 
large a role, if not larger, in promoting a sustainable, inclusive economy that increases the well-being of the many, rather than the few." 15

Following in this vein, Thomas J. Horton presents "Fairness and Antitrust Reconsidered: An Evolutionary Perspective" 16 and writes, "[I]n eschewing norms of fairness in our antitrust analyses and theories, we have moved away from our evolutionary heritage and are in danger of becoming "moral zombies" and economic sociopaths." notes that even the decision to violate or risk violating the antitrust laws may involve cultural norms that are not easily captured by cold economic calculations. ${ }^{18}$ Moreover, unlike United State antitrust law, European Competition law can be brought to bear against firms simply because their prices are found to be too high. ${ }^{19}$

For the reader who does not follow antitrust law, a response to these observations might be "what is the big deal?" After all isn't all law, whether it works or not, ultimately about fairness, justice, or wellbeing? The news for those readers is, not by a mile. For example, those who follow the neoclassical model write about maximizing consumer surplus and allocative efficiency. Consumer surplus actually focuses on the "welfare" of some consumers some of the time. Allocative efficiency is ultimately another label for wealth maximization, a goal that is quite different from welfare maximization. ${ }^{20}$ These terms are misleading and can mask a number of interests that concern reasonable people. In its other form, antitrust is driven by a purely political agenda about the appropriate role of government. ${ }^{21}$ Sometimes the second form hides

15. Id. at 2645 .

16. Thomas J. Horton, Fairness and Antitrust Reconsidered: An Evolutionary Perspective, 44 MCGEORGE L. REV. 823, 823 (2013).

17. Id. at 863. See also Adi AYAL, Fairness in ANTITRust: Protecting the Strong From THE WEAK (2014).

18. D. Daniel Sokel, Cartels, Corporate Compliance, and What Practitioners Really Think About Enforcement, 78 ANTITRUST L. J. 201, 223 (2012). See generally Horton, supra note 16, at 824. 173.

19. Treaty Establishing the European Community (E.C. Treaty) art. 82(a), 1997 O.J. (C 340)

20. Allocative efficiency can be equated with the goal of wealth maximization or KaldorHicks efficiency. For a brief history of "efficiency" and its limitations see Jeffrey L. Harrison, Happiness, Efficiency, and the Promise of Decisional Equity: From Outcome to Process, 36 PEPP. L. REV. 935, 942-46 (2009). This is not the place for a full discussion of wealth maximization as a goal except to say it is a cobbled together version of efficiency that is not consistent with actual well-being.

21. The non-interventionist approach can be reconciled with an economic approach only if one accepts that the only difference is based on whether markets, in some time period, are selfcorrecting. See generally Alan Devlin \& Michael Jacobs, The Empty Promise of Behavioral Antitrust, 37 HARV. J. L. \& PUB. POL'Y 1009, 1061-62 (2014). See also Michael S. Jacobs, An Essay on the Normative Foundations of Antitrust Economics, 74 N.C. L. REV. 219 (1995). Even in its 
behind the first, but, in its second form, the concern of consumer welfare is nominal.

This Article demonstrates the relationship between socioeconomics and antitrust law. It uses socio-economics to both deconstruct the current economic foundation of antitrust policy and to suggest ways to improve that policy. There are four steps in this presentation. Part II examines the core elements of the economic approach to antitrust and its shortcomings, if any. ${ }^{22}$ For those even moderately versed in economics, it will note that the analysis begins at the most basic level. Obviously, antitrust is designed to make markets more competitive. But that goal is merely a means to the end of greater consumer surplus ${ }^{23}$ and allocative efficiency. ${ }^{24}$ Part of what follows is designed to pierce the meaning of those goals. Part III describes why current antitrust, at least at the Supreme Court level, cannot be squared with the economic approach and, thus, reflects a narrow political philosophy. In fact, in this respectbecause it is faith-based-there may be little room for a socio-economic perspective. That approach is non-falsifiable and, while important, it is resistant to a thoughtful analysis. In Part IV, the discussion turns to how the limitations discussed in Part II may provide the predicates for altering current antitrust policy. While Part V does not reveal a plan for revamping antitrust, it instead provides portals through which those who accept that today's approach is imperfect may want to look.

\section{THE BASICS}

\section{A. Nominal Antitrust Goals}

It is a very basic question: Why do we care about competition? Competition cannot be an end in itself; it must result in something that is consistent with greater welfare, however defined. ${ }^{25} \mathrm{~A}$ short review of the

economic form the belief in self-correction is based on faith. For the uninitiated, there are numerous labels floating around which are applied to different approaches to antitrust law. One useful catalogue is found at Max Huffman, Marrying Neo-Chicago with Behavioral Antitrust, 78 ANTITRUST L.J. 105, 108-12 (2012).

22. The current economic approach is based on neoclassical economics. Another approach, described shortly, is not fully grounded in economics.

23. See infra notes $28-29$ and accompanying text.

24. See infra notes $29-30$ and accompanying text.

25. A related issue is whether competition should be fair. As Judge Easterbook, in a typical "full of himself" style once observed, "Who says competition is supposed to be fair . . ?" Fishman v. Estate of Wirtz, 807 F.2d 520, 577 (7th Cir. 1986). He might also ask: "Why should the rules of basketball or football be fair?" Fairness is important in legitimizing-making acceptable-any process in which there are winners and losers. 
economics of antitrust illustrates what the ends are. Figure 1 illustrates the basic model of supply and demand under competitive conditions. Price is along the $\mathrm{Y}$ or vertical axis and quantity along the $\mathrm{X}$-axis. The Demand curve (D) is downward sloping, indicating that at higher prices buyers are willing and able to purchase fewer units of output. ${ }^{26}$ The supply curve is upward sloping indicating that as prices increase sellers are willing and able to sell more units of production. ${ }^{27}$ If the market is sufficiently competitive, prices in this market will gravitate toward the intersection of supply and demand. This is at P. The corresponding level of sales will be $Q$. The reason for this is fairly obvious. At prices above $P$, a greater quantity will be available for sale than demanded, and this surplus will tend to push prices lower. At prices below $P$, the amount demanded will exceed what is available for sale and prices will tend to rise. $P$ represents equilibrium.

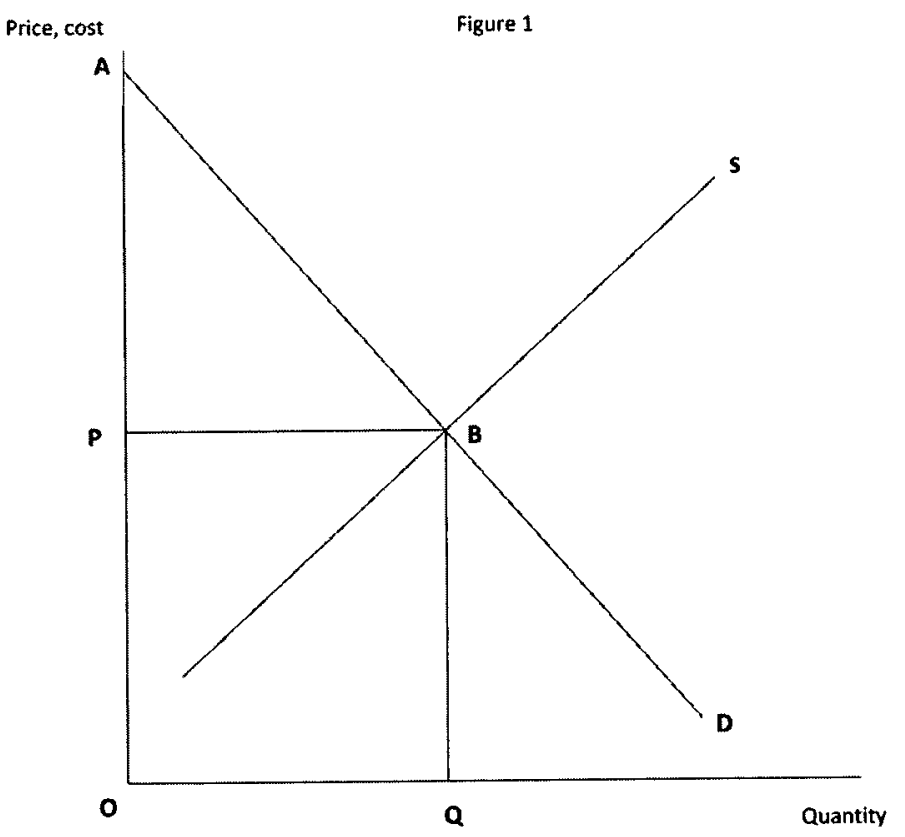

26. An easy way to think about demand is to imagine a list of possible prices being passed around to a group of people in a market. Each writes down how much they would buy at each price. These quantities are then summed to determine the quantity demanded at each price.

27. Typically for simplicity's sake, supply curves are portrayed as upward sloping. In reality, they may be flat over an extended range of production levels. 
Subject to a number of possible qualifications, which do not affect this analysis, antitrust policy, at least nominally, is designed to prohibit some business practices that interfere with an adjustment to $\mathrm{P}$, the equilibrium point. To understand the attraction of this goal, it is important to see demand and supply in a slightly different light. Demand does show how much would be purchased at each price. If the focus is on quantity, it also shows the most people would be willing to pay in order for that quantity to be purchased. The same is true of supply. It shows how much would be offered at each price, but it also can be read to show the least sellers would take to sell a specific level of output.

This perspective enables us to understand consumer surplus. Consumer surplus is the difference between the price consumers pay and the most they would pay for an item. In a sense, it is the consumer's benefit of the bargain. For example, in the graph the price is $P$. If you compare that price with the most consumers are willing to pay at every quantity less than $Q$, it is clear that consumers "value" the output by more than the price of $\mathrm{P}$. For all those units there is consumer surplus. The total in this particular market is the triangle PAB.

The term consumer surplus is distinguished from another goalallocative efficiency. Again, focusing on each quantity to the left of $Q$, the value attributed to the good by buyers exceeds the lowest price acceptable to sellers. ${ }^{28}$ To understand allocative efficiency it is important to understand how that lowest price is determined. In theory, each seller will not take less than the costs of the inputs necessary to produce a unit of output. The cost of inputs is determined by the markets in which producers must make purchases of inputs. In those markets they compete with other buyers of inputs. To actually buy the input the supplier must outbid other potential users of that input. The highest bidder is the one who can put the input to its best use as determined by how much demanders are willing to pay for what is eventually produced. In a sense the cost to society of the input is the price paid to take it from the production of other goods.

Now look again at every quantity to the left of $Q$. At each quantity there is a measure of the value attributed to the good produced (demand) and the cost to society of having that good produced (supply). Thus, we say production level Q is allocatively efficient because for all levels of output up to that point the value attributed to the good exceeds the cost to society of producing it. In fact, if everything "works," the market is

28. That vertical distance has two parts. The part above the market price is consumer surplus. The segment below price is producer surplus. 
like a giant vacuum cleaner sucking inputs into markets in which they are best used to satisfy demand. No one actually believes this is a static phenomenon, ${ }^{29}$ nor that the competitive conditions exist under which it would be possible. Antitrust law, though, is supposed to push markets to the competitive ideal.

One way to understand the desirability of a competitive outcome is to examine Figure 2, which includes $P$, now labeled $P_{1}$, and $Q$, now labeled $Q_{1}$, but also includes price $P_{2}$ that exceeds $P_{1} . P_{2}$ could be the result of competitors engaging in price fixing or the market being controlled by one firm. Without competition the price does not fall to $P_{1}$, the competitive level. Two outcomes are obvious and are at the center of current antitrust policy. First, output has declined from $Q_{1}$ to $Q_{2}$. This production stops short of the allocatively efficient level. Also, since price has risen, fewer units are purchased. Those that are no longer purchased account for no consumer surplus. In fact, at the new price, consumer surplus has decreased from $\mathrm{P}_{1} \mathrm{AB}$ to $\mathrm{P}_{2} \mathrm{AD}$.

29. In fact, the process is a constant one in which equilibrium can be compared to a gravitational pull that is constantly in flux. 


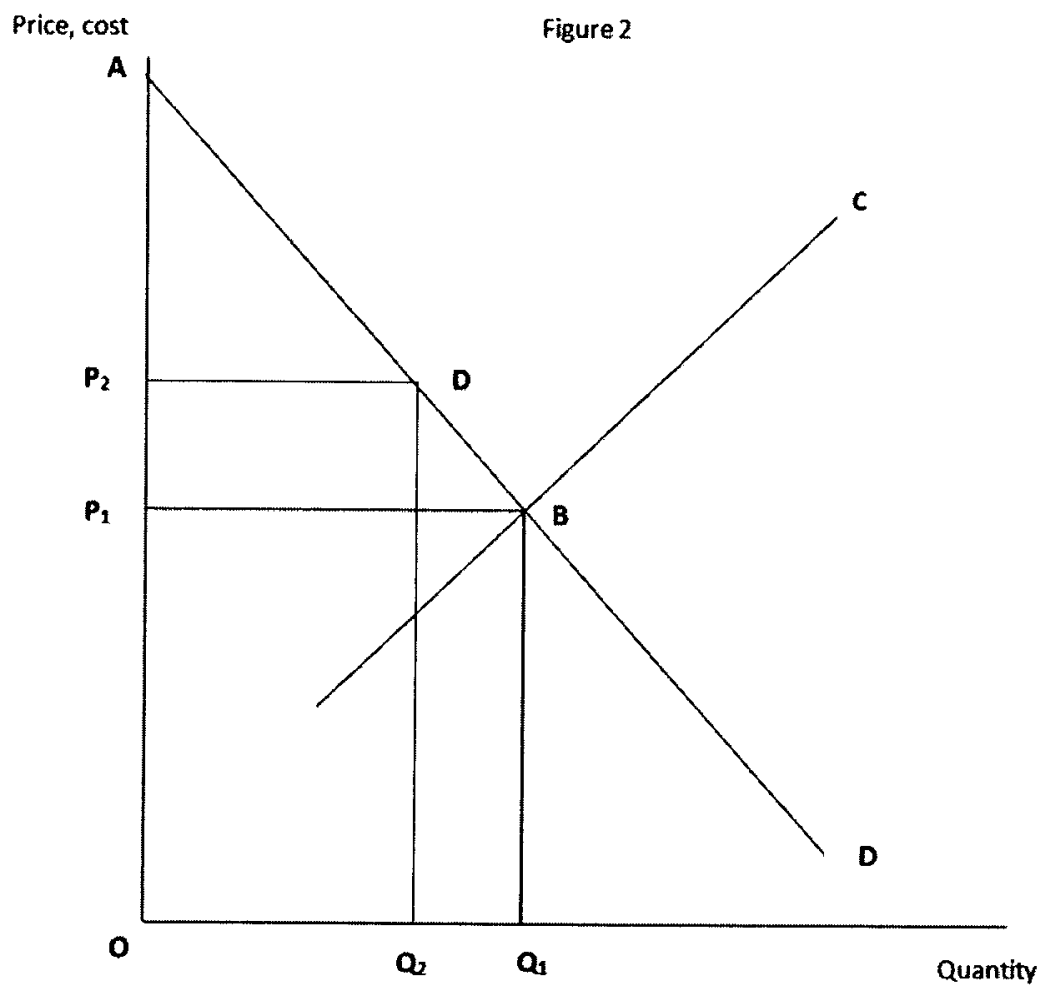

B. The Missing Elements.

There are many qualifications to the model that are important to understand even if one is not inclined to take a socio-economic approach to antitrust. Let's start with the supply curve. Again, it is determined by what it costs to bring inputs into the production of a particular good. The desired cost is the lowest cost possible at the equilibrium level of output. In reality, the costs examined by antitrust courts and enforcement agencies may understate actual cost. The model only incorporates costs that are incurred, or internalized, by the firm. For example, a producer could be a polluting factory in a country with a relaxed attitude toward pollution. Smoke from the factory or waste deposited into a river may negatively impact the longevity of those who live for miles around. The point is that the cost and therefore the supply curve that comprises the model upon which the antitrust theory relies has been "sterilized," and the real "cost" of the costs are not revealed. There is a great deal of talk 
about efficiency, but in antitrust, efficiency is based on internalized costs, not full costs. As noted later, the ability to externalize costs may differ from firm to firm, which means viewing one firm as more efficient than another is based on guesswork.

More serious issues arise with demand. It is important to recall that demand requires that people be willing and able to purchase an item. A need, even the severest need, is not reflected on the demand curve if it is not manifested by people with dollars to spend. Thus, quite literally, it may be more "efficient" to produce yachts than it is to provide prenatal care for poverty-level, expectant mothers. In effect, antitrust law is only about those with the means to express themselves in market. If dollars were votes, those without them are disenfranchised. To be fair, if prices are lower due to increased competition, more people are able to be heard in the market; however, those with fewer dollars will always speak more quietly.

The "willing and able" element is hardly a surprise. What is perhaps more interesting is that even when people express themselves in the market, it is difficult not to view it with suspicion. Market participation is a way some people express their preferences. But the sources of those preferences vary greatly from requiring medication, to relieving a painful ailment, to purchasing a weapon with the intent to harm someone, to associating a brand of beer with being adventuresome or attractive after watching scores of television commercials. Some are the result of outside sources creating a sense of need where none would otherwise exist. ${ }^{30}$ In fact, the demand curve may reflect not much more than a seller's skill at manipulating tastes.

More troubling is the fact that it cannot be determined if the person making the transaction is better off in any meaningful sense or whether he or she actually experiences the so-called surplus. The preferences one expresses at the time of the purchase is one thing; the actual experience another. ${ }^{31}$ This analysis undercuts the connection between the economist's notion of consumer surplus and actual well-being. Consequently, the goal of maximizing consumer surplus as currently understood, may be off the mark in terms of achieving what it purports to achieve.

30. This leads to the question of whether consumer surplus is actually the same as relieving feelings of need or desire. If so, acquisition is but one way to resolve the problem. See Harrison, supra note 20, at 951-54; Stucke, supra note 14, at 2630-31.

31. The difference between expected utility and actual utility has been explored by Daniel Kahneman and others. See Daniel Kahneman, et. al., Back to Bentham: Explorations of Experienced Utility, 112 Q.J. ECON. 375, 386 (1997). 
This can be understood by reviewing Figure 3, which includes the same supply, demand and equilibrium points as Figure 1. Remember that the demand curve reflects willingness and ability to pay based on beliefs about the future and the anticipated satisfaction or usefulness of the actual product. Suppose we could draw a demand curve for what people are willing and able to pay if they knew exactly how satisfactory the product would be. Or this could be viewed as willingness and ability to pay as honestly reported after having experienced the product.

This experienced demand could be above, below, or the same as the expectations based demand curve. Only in the last case would antitrust policy be in sync with actual welfare, but even here it is welfare of those able to pay. All possibilities are open. For example, one could say that people are willing to pay less before they actually acquire the good because they know the eventual utility it will deliver is risky. On the other hand, the source of information about expected enjoymentsellers - is most likely to lead buyers to have high, and possibly unrealistic, expectations. The market of information about actual use is less organized and less persistent.

The graph depicts the experienced-based demand curve as $D_{2}$. As illustrated, people would pay less to take each quantity off the market if they knew in advance what utility the use of the product would bring. $D_{2}$ is consistent with some level of disappointment. In the graph, expected consumer surplus is PAC. Gross experienced consumer surplus is PBE. The area ACEB represents an overpayment for which consumers derived no utility and, presumably, could have been used for expenditures that would have resulted in actual consumer surplus. The net consumer surplus in the competitive market is less than PBE. At quantities in excess of $\mathrm{Q}_{2}$, consumers who pay the market price experience a loss of actual welfare. This is indicated by the fact that demand or experienced demand is below the market price. If this loss is subtracted from the area PBE, the net experienced consumer surplus is PFDB.$^{32}$ This reflects the decreased consumer surplus for those who experienced some consumer surplus and the pure loss by those who experienced negative consumer surplus.

32. One could argue that I have changed the assumption of the model in the sense that it assumes perfect information and, if there is perfect information, there will be no disappointment. The relevance of this is not entirely clear since relaxing the assumptions of air-tight models is one method of bringing reality to bear in policy. In any case, one could just as easily argue that there is perfect information even with respect to $D_{1}$ in Figure 3 because people know they cannot know the precise outcome. And, in the context of $\mathrm{D}_{2}$, there is also perfect information of a different type. 


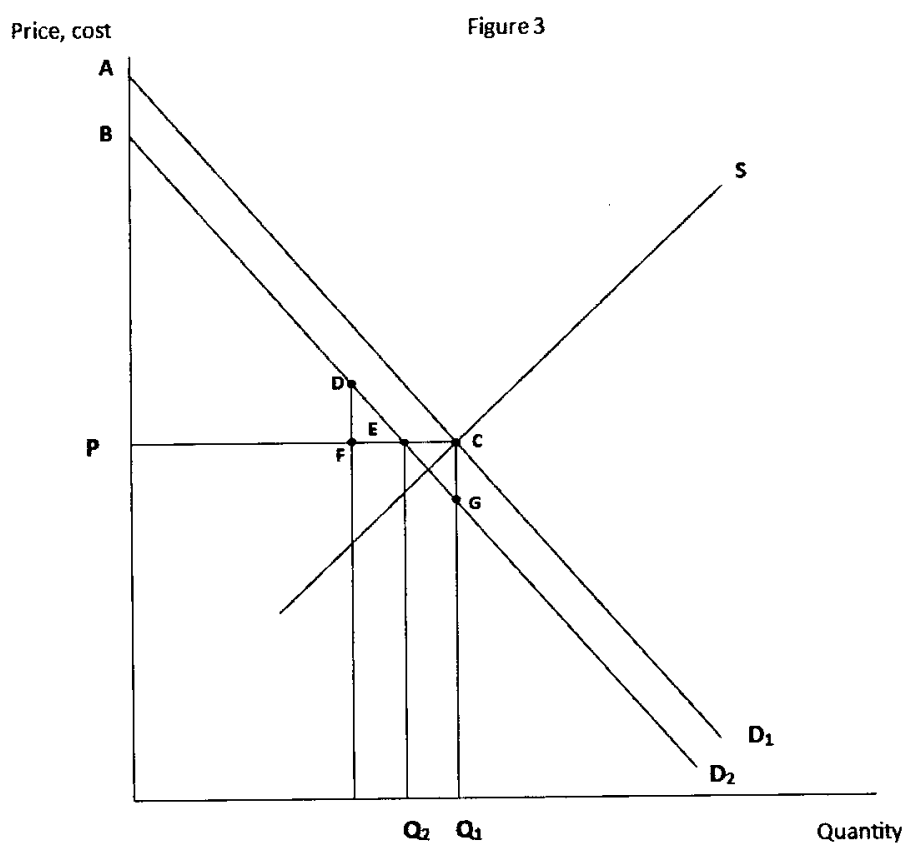

Finally, recent events suggest another problem related to the interdependency of supply and demand. Low costs for some inputs may reflect a cost of labor in a third world country that is exploitative. Some people may have a preference for goods produced at a higher cost, perhaps by people in the United States, or by those paid more than the lowest possible wage in foreign labor markets. This preference should reveal itself in the demand curve but it is not always clear that it doesespecially if the information is not evident from examining the label. ${ }^{33}$ The demand curve is, thus, false in the sense that it does not reflect informed demand. There are economic reasons for this lack of information. It may be more expensive to produce information than consumers are willing to pay. One could say it is inefficient to be better informed. On the other hand it is just as likely that a buyer would value the information, but the producer is better off if it is not disclosed.

The limitations of efficiency in the context of antitrust can be understood by thinking about the things people value that have little to do with market transactions. Some theories have suggested that human

33. The country of origin is required on imported goods but this may or may not be an accurate indication of working conditions. 
needs exist in a hierarchy. In the hierarchy of Abraham Maslow, ${ }^{34}$ these range from physiological to self-actualization. Maslow's hierarchy may be dated, and there are criticisms, ${ }^{35}$ but they are mainly based on the ordering and stability rather than the hierarchy's existence. Moreover, it is common sense that, in most societies, people are concerned first with food, shelter, and basic needs. If those needs are satisfied, their concerns turn to different types of needs. The ordinary market transactions of most healthy people are concentrated near the bottom of the hierarchy. At the top of the hierarchy may be things like love and self-esteem. Perhaps these feelings can be acquired through market transactions, but, if so, those markets are very poorly defined. Consequently, it is important to bear in mind that what antitrust economics calls consumer surplus may only scratch the surface of things that are of value. Perhaps antitrust can be designed to maximize consumer surplus, but that effort may be comparable to fine tuning one string on a 12 string guitar. Unless the remaining strings are also in tune, the sound produced will remain discordant.

Finally, if the notion of efficiency has any meaning, it must be that scarce resources are used to make people better off. Feeling better off, however, may actually be a consequence of how specific markets work. For example, a person who is concerned about widespread possession of guns, the least competitive market with the highest price and lowest output of guns could be desirable. On the other hand, when it comes to necessities, it is possible that many or most people would prefer competitive markets with the highest output and lowest prices possible. In a sense, what antitrust misses is that there may be preferences for different levels of competition in different markets. These demands may not reveal themselves because of free riding or because there simply is not a market for varying degrees of competition. Nothing about those limitations disqualifies those preferences as sources of well-being.

\section{THE “ECONOMICS” OF TODAY'S ANTITRUST POLICY}

The discussion above starts from the assumption that today's antitrust is about some version of economic well-being. Before describing the potential (and, admittedly, the difficulties) of a more

34. Abraham H. Maslow, Motivation and Personality (2d ed. 1954). See generally Mark A. Lutz \& KenNeth LuX, The Challenge of Humanistic ECONomics (1979).

35. See e.g., Dorien T. A. M. Kooij, et. al., Age and Work-Related Motives: Results of a Meta-Analysis, 32 J. ORganizational Behav. 197 (2011); Christopher Peterson \& Nansook Park, What Happened to Self-Actualization?: Commentary on Kenrick et al. (2010), 5(3) PERSP. OF PSYCHOL. SCI. 320 (2010). 
socio-economic approach, it is important to note that there is a more faith-based, politically-driven version of antitrust law now favored by the Supreme Court. This approach may be displacing one based on economics of any kind. The guiding principle of today's antitrust approach of the Supreme Court is much more aligned with doing nothing, even when enforcement of the antitrust laws would achieve the goals of more consumer surplus (as traditionally defined) and allocative efficiency. In the end, it reflects a deep-seated distrust of government involvement in economic affairs. Its principal nominal defense is based on the risks of false positives and false negatives. False negatives occur when a firm is incorrectly found not to have behaved in an anticompetitive manner. Conversely, a false positive occurs when a firm that is not engaged in an anticompetitive activity is found to have violated the antitrust laws. The Court has a pronounced bias in favor of avoiding false positives. ${ }^{36}$ Although other than an incurred cost of enforcement, there is no known basis for believing false positives are more harmful than false negatives.

The false positive obsession is but one way an economic approach has been replaced by a philosophy of minimizing the role of the antitrust laws. Another manifestation is the treatment of those possessing monopoly power. One rarely mentioned problem with monopolies is that those who gain from them nearly always do more harm to others than the amount gained by the monopolist. ${ }^{37}$ In fact, because those who are made worse off are more worse off than those benefitting are better off, if a transaction could take place, those harmed would buy the right not to be subject to the monopolist's profit maximizing efforts. ${ }^{38}$ This would be consistent with what is at the heart of the law and economics approach to law, the Coase Theorem. ${ }^{39}$ There are exceptions to this buyout transaction. The cases in which those subjected to monopoly power would not favor such a transaction include only those in which the monopolist creates an offsetting benefit. ${ }^{40}$ At the very least, this would suggest monopolists should shoulder the burden of proof with respect to

36. See generally Alan Devlin \& Michael Jacobs, Antitrust Error, 52 WM. \& MARY L. REV, 75 (2010).

37. See Jeffrey L. Harrison, An Instrumental Theory of Market Power and Antitrust Policy, 59 S.M.U. L. REV. 1673, 1682 (2006).

38. Id. at 1674,1681 .

39. R. H. Coase, The Problem of Social Cost, 3 J. L. \& ECON. 1, 2 (1960). The idea presented here is that the elimination of monopolists would be a market mimicking rule and those truly devoted to market solutions would be proponents of a much closer look at a firm's possession market power.

40. See Harrison, supra note 37 , at 1679-81. 
the benefits they create. However, the current approach to Section 2 of the Sherman Act is one that results in an exceedingly narrow scope of liability. ${ }^{41}$

A further manifestation is found in the current emphasis on market power, market share, and market definition. A little background will make this clearer. As antitrust evolved, various types of behavior came under one of two standards. Some behavior, like price fixing, was, and to some extent still is, per se unlawful. This meant that arguments that prices were reasonable or the effort ineffective were irrelevant. Other behavior was (and is) subject to the "rule of reason." Under that standard, at least in theory, the pro and anticompetitive effects of the practice are weighed. ${ }^{42}$ Over the past few decades, the Supreme Court has switched practices that were per se unlawful to the rule of reason. ${ }^{43}$

The first step in virtually all rule-of-reason cases ${ }^{44}$ is the process of determining the market power of the defendants to assess whether what they were doing created a danger of an anticompetitive impact. It has been argued that the entire process is imprecise, subjective, and adds tremendous costs to plaintiffs. ${ }^{45}$ Plus, in some instances it is irrelevant. For example, under Section 2 of the Sherman Act it is a violation to attempt to monopolize. ${ }^{46}$ The courts adopted the view that it is not an attempt to monopolize unless there is a dangerous probability that the firm engaging in the questionable activity will become a monopolist. ${ }^{47}$ The determination of dangerous probability requires a market definition and a determination of market share to assess how close the defendant is to achieving market power. Yet, the market share a firm possesses may be a very thin indicator of the likelihood that a firm will actually become a monopolist. Many types of anticompetitive behavior require the firm to incur actual losses in the short-term that will be presumably be made up after the firm becomes a monopoly. ${ }^{48} \mathrm{~A}$ firm with a $50 \%$ market share,

41. See generally C. Paul Rogers III, The Incredible Shrinking Antitrust Law and the Antitrust Gap, 53 U. Louisville L. REV. 67 (2013); Diana De Leon, The Judicial Contraction of Section 2 Doctrine, 45 LOY. L.A. L. REV. 1105, 1109-10 (2012).

42. The pivotal case in this development was Continental T.V., Inc. v. GTE Sylvania, 433 U.S. 36,49 (1977).

43. This has occurred in the context of both vertical and horizontal restraints. See generally SULLIVAN \& HARRISON, supra note 2, Chapters 4 \& 5.

44. A possible exception involves cases in which an anticompetitive effect can be shown directly. See, e.g., F.T.C. v. Ind. Fed'n. of Dentists, 476 U.S. 447, 452 (1986).

45. Richard S. Markovits, The Limits to Simplifying Antitrust: A Reply to Professor Easterbrook, 63 TEX. L. REV. 41, 58 (1984).

46. 15 U.S.C. $\$ 2(1890)$.

47. See generally SULLIVAN \& HARRISON, supra note 2, at 323-24.

48. These losses can be in the form of actual losses or in profits forgone. Predatory pricing is, 
despite trying, may have too little in the way of reserves to sustain the period of losses. On the other hand, a firm with a $20 \%$ market share may be well funded and far more likely to succeed. In effect, financial capacity is a better measure of the likelihood of success than market share. ${ }^{49}$

Most telling in the realm of today's faith or ideological-based approach to antitrust is the fallacy of the rule of reason and the idea that pro and anticompetitive effects are balanced. ${ }^{50}$ In the typical rule of reason case the plaintiff must carry the burden of demonstrating an anticompetitive effect. If it survives a motion for summary judgment, the burden shifts to the defendant to offer a competitive justification. ${ }^{51}$ In an important study of 222 cases between 1999 and 2009, Michael Carrier found that in only five cases did the balancing process actually occur, and in only one case did the plaintiff prevail. ${ }^{52}$ The role of market analysis is a huge factor. Of the 217 cases in which there was no balancing, most of the outcomes were based on the failure to satisfy the market definition/market power requirement. ${ }^{53}$ In total, Carrier found that $95 \%$ of the rule-of-reason cases involved no balancing of pro and anticompetitive effects. ${ }^{54}$ It might be reassuring if in $95 \%$ of the challenged actions there was no traditionally defined competitive harm. However, that seems unlikely to be the case. The ideological approach creates another danger. Regardless of the merits of a potential plaintiff's claim, the costs and risks are daunting, and there seems little doubt that the ideological approach shelters many economically harmful activities. ${ }^{55}$ Increasingly, the emphasis on avoiding false positives looks less like an empirical assessment and more like a view that the antitrust laws should be rarely, if ever, invoked.

is of course, the principal example of incurring losses.

49. See RICHARD S. MARKOVITS, ECONOMICS AND THE INTERPRETATION AND APPLICATION OF U.S. AND E.U. ANTITRUST LAW 524 (2014).

50. See generally Michael A. Carrier, The Rule of Reason: An Empirical Update for the 21st Century, 16 GEO. MASON L. REV. 827 (2009); Nicole McGuire, An Antitrust Narcotic: How the Rule of Reason is Lulling Vertical Enforcement to Sleep, 45 LOY. L.A. L. REV. 1225, 1228-29 (2012).

51. Carrier, supra note 50 , at 827 .

52. Id. at 829 .

53. Id. at 830 .

54. Id. at 829 .

55. This is best exemplified by a focus on avoiding false positives, which means knowingly allowing anticompetitive activities to continue. 


\section{A ROLE FOR SOCIO-ECONOMICS?}

As noted at the outset, the principal role of socio-economics is to question convention. In a sense, it does not matter if the status quo is retained. Perhaps the socio-economic approach would actually lend support to the status quo. The analysis above, however, demonstrates that neoclassical-based antitrust policy has only weak underpinnings. Can things be improved? That is not entirely clear, but it is likely. But first, it is important to note there is likely to be resistance. Those wedded to a particular view about the very limited role of government in public affairs are uninterested in anything that would suggest that greater enforcement of the antitrust laws is warranted. Similarly, those who are devoted to the neoclassical model are often not convinced that socioeconomics has much to offer. ${ }^{56}$ This resistance also comes from more serious antitrust scholars. Although it is perhaps unfair to generalize, there exists almost a literal defensiveness about the neoclassical model. This may reflect the inertia that any status quo paradigm enjoys. ${ }^{57}$ In the field of economics, one commentator captures this:

This dominant neoclassical paradigm defines what counts as economics, and who counts as an economist. Anyone not sharing these assumptions is often deemed not to be an economist. Because they don't conform to the principles of the ruling paradigm, they find it difficult to get published in leading economic journals and to get recognized within the academy. The problem is there are many scholars who study the economy, and who consider themselves economists, yet whose work is not considered legitimate by those working within the neoclassical paradigm. ${ }^{58}$

In economics generally, as well as antitrust economics, this means that rather than taking a neutral stance that seeks ideas and insights to improve antitrust, the prevailing view is to shift the burden to those offering new insights to prove that they have something to offer. Since many of those writing in the field of antitrust economics are lawyers, they can bring a particularly strong adversarial attitude to the discussion. ${ }^{59}$ Indeed, the level of ridicule, defensiveness, and dismissal

56. See infra notes 59-61 and accompanying text. 1962).

57. See generally Thomas S. Kuhn, The Structure of SCIENTIFIC ReVolution (2d ed.

58. Damien Cahill, Why Does Neoclassical Thinking Still Dominate Economics?, THE CONVERSATION (October 17, 2011), http://theconversation.com/why-does-neoclassical-thinkingstill-dominate-economics-3861.

59. See, e.g., Devlin \& Jacobs, supra note 36, at 130; Joshua D. Wright \& Judd E. Stone II, Misbehavioral Economics: The Case Against Behavioral Antitrust, 33 CARDOzo L. REV. 1517, 
borders on a kind of intellectual bullying. ${ }^{60}$ Instead, antitrust scholars would be more productive if they took part in the search for ways to refine the models to account for what even common sense can identify as flaws.

In fairness, to some extent, inertia is a product of the system itself. Antitrust laws are enforced by the US. Justice Department, the Federal Trade Commission, and private actions. While one might expect public enforcement agencies to adopt a more nuanced view of consumer surplus and ailocative efficiency in case selection, that is an unrealistic expectation in the context of private actions. In addition, within the judicial system, a more nuanced view would be regarded as highly activist and subject to reversal. Consequently, as a practical matter, it does not appear that the limitations identified here could be addressed in the short run.

On the other hand, despite this gloomy outlook, the fact is that antitrust law does evolve, and there is no statutory reason why it could not evolve further. An example is useful here. In one of the best known passages found in an antitrust case ${ }^{61}$ (and one that is likely to make today's antitrust scholars cringe), the Court was faced with whether it is preferable to have an "efficient" monopoly or competition among a number of smaller and perhaps less efficient competitors. The reasoning, by today's standards, is remarkable:

Of course, some of the results of large integrated or chain operations are beneficial to consumers. Their expansion is not rendered unlawful by the mere fact that small independent stores may be adversely affected. It is competition, not competitors, which the Act protects. But we cannot fail to recognize Congress' desire to promote competition through the protection of viable, small, locally owned business. Congress appreciated that occasional higher costs and prices might result from the maintenance of fragmented industries and markets. It resolved these competing considerations in favor of decentralization.

1535 (2012). A more productive approach is found in Alan Schwartz, Regulating for Rationality, 67 STAN. L. REV. 1373, 1375 (2015). Outside the box thinking about a specific antitrust issue that should be encouraged is represented by Jennifer E. Sturiale, Variety, Mergers, and Consumer WellBeing: Toward a Capability Approach to Merger Law, 117 W.VA. L. REV. 135, 136 (2014).

60. This resistance is not limited to the ideas proposed by behavioral economists; it actually extends to economists more generally who are unwilling to toe the line of conventional teachings. Richard Markovits, an accomplished antitrust economist, has for three decades now written about the shaky foundations of the convention approach to economics. See generally MARKovITs, supra note 49 . Yet his writings, although not ignored, seem to have gained very little purchase among scholars, courts or enforcement agencies.

61. Brown Shoe Co. v. United States, 370 U.S. 294, 312-14 (1962). 
We must give effect to that decision. ${ }^{62}$

This passage is an obvious recognition of a value that is unlikely to be expressed in the market. The principal problem is that the protection of viable, small, locally owned businesses takes on the character of a public good. There are many that would pay a few dollars more to have several locally owned stores, but that cannot happen if there are free riders or holdouts. We know that these preferences exist and are not reflected in voluntary markets. This calls for applying a critical perspective to antitrust law.

Caution about a socio-economic approach may also arise from the sense that it is difficult to measure some of the values of socioeconomics. This is not a reason for ignoring them. The approach is inconsistent with what routinely goes on within the public policy realm. It is a necessary step in discovering the best decision, whatever the goal. We do it all the time. One of my favorite actions reflecting this involves the decision by the Food and Drug Administration to limit the distribution of cigarettes to minors. ${ }^{63}$ The detailed analysis of costs and benefits extended costs to consumers "to the extent that they lose positive utility from the imagery embodied in product advertising campaigns." ${ }^{24}$ For example, people may have felt better by smoking Marlboro cigarettes because they felt like they resembled the Marlboro Man. If this were the case, they would be made worse off by less advertising. In sum, the costs that may not appear in the market are no less relevant than those on an income statement, and antitrust law ignores some of the most relevant costs.

\section{A. Socio-economic Portals: Consumer Surplus}

Interestingly, the costs of cigarettes played a role in an important Supreme Court case that illustrates the potential for socio-economics. In Brooke Group v. Brown and Williamson Tobacco Corp. ${ }^{65}$ the Supreme Court addressed the issue of what would constitute predatory pricing. It concluded that prices that were below cost were suspect in that a firm would not charge prices that low unless it anticipated excluding competitors and then be able to raise prices in order to recoup the losses

62. Id. at 344 .

63. Regulations Restricting the Sale and Distribution of Cigarettes and Smokeless Tobacco Products to Protect Children and Adolescence, 60 Fed. Reg. 41314 (proposed Aug. 11, 1995).

64. Id. at 41360 .

65. 509 U.S. 209 (1993). 
incurred during the predatory period. ${ }^{66}$ Think about this decision in the context of a body of law designed to encourage increased consumer surplus and allocative efficiency. An effort to maximize consumer surplus would presumably mean increasing the good feelings of being associated with the advertising of cigarettes - the type of thing recognized by the Food and Drug Administration in the consideration of cigarette advertising discussed above. In fact, greater competition means more of just this sort of advertising. Should antitrust be employed to maximize all forms of consumer surplus, even those who are harmed while enjoying the surplus in the short run? The point is that a general reference to consumer surplus as being desirable is often inconsistent with common sense and reflects adherence to a very crude measuring stick.

The neoclassical argument in response to this is that the harms caused by the use of some products would be manifested on the supply side of the usual model. In theory, harms caused by smoking would eventually be internalized by manufacturers, supply would decrease, quantity would fall and price would increase. Those still smoking would be those who are willing to pay all the costs of production and still derive a benefit. This, of course, assumes greater rationality than is possible and decisions made in the absence of addiction.

The smoking example is evidently a popular one ${ }^{67}$ but hardly isolated. It illustrates at least three flaws in current antitrust thinking. First, it attributes the same weight to all consumer surplus even when current enjoyment of the consumer surplus leads directly to consumer misery later. It ignores the power of addiction. Finally, it means the costs of production are understated.

The question is then, how, on a principled basis, could antitrust distinguish between types of consumer surplus. There are no precise principles, but there are some things we know. First, the neoclassical model of consumer surplus is only remotely connected to actual consumer well-being. Second, as noted above, some demand is the result of addiction. In many of those instances, consumers may derive great consumer surplus while at the same time wishing they did not experience the addiction at all. In a sense, they derive consumer surplus, but they would also experience a kind of welfare or "surplus" if they did not have a preference for smoking.

66. Id. at 224 .

67. See Sturiale, supra note 59 , at 154 . 
This may introduce some normativity and subjectivity into the assessment of consumer surplus. However, the decision to treat all forms of consumer surplus-whether from conspicuous consumption, addiction, or lifesaving medical treatment, all of which consume scarce resources-is no less normative and far more questionable. It is a decision to cede to those with money the control of how resources are allocated, often without regard to actual welfare.

Another group of examples concerns appeals to vanity or bandwagon effects. ${ }^{68}$ Here, the features of a product can be separated into its functional elements and nonfunctional elements. For example, functional elements include things like: does the sweater keep you warm and does the food deliver the expected nutritional factors? Nonfunctional would refer to: do people attribute a higher status to me if I own a yacht or wear clothing with a certain label? Whether it is actual harm or envy, some consumer surplus exists only because it makes others worse off. In fact, some markets exist almost exclusively to serve the competitive impulses of consumers as they seek to achieve higher consumer surplus by besting others. By making these markets more competitive, it could actually reduce consumer surplus for some and increase it for others. But more importantly, what would be the rationale for bringing antitrust to bear on markets in which the real competition is among consumers in the interest of vanity? Ultimately no one may be better off, yet inputs are poured into a market like they might into an ill-advised war.

Earlier it was demonstrated that actual and expected consumer surplus might vary. Ideally, antitrust policy should be about actual, not expected, outcomes that do not materialize. Obviously, even if neoclassicists were open to this idea, it is still difficult to implement. It is, however, possible that this is one area where socio-economics may complement the conventional analysis. The "actual" as opposed to "expected" problem might be, in part, the result of a lack of competition. The key is to bring demand curve $D_{1}$ and $D_{2}$ in Figure 3 closer together. More competition may do this. Unless it is clear the result will occur, the rationale for making the market more competitive becomes less compelling.

68. See generally H. Leibenstein, Bandwagon, Snob, and Veblen Effects in the Theory of Consumer Demand, 64 Q.J. ECON. 183 (1950); Jeffrey L. Harrison, Trademark Law and Status Signaling: Tattoos for the Privileged, 59 FL. L. REV. 195, 227 (2007); Stucke, supra note 14, at 2630-32. 


\section{B. Socio-economic Portals: Allocative Efficiency}

Consumer surplus, demand, and supply all come into play when considering allocative efficiency. The principal focus is on the supply or cost side of the equation. Here again, cigarettes and the Brown and Williamson $^{69}$ decision are useful. And, to some extent the socioeconomic message here may be that courts are not applying simple economics. In that case, the court announced that the cost of producing cigarettes was a key issue. ${ }^{70}$ But, it is unlikely that any antitrust court in an antitrust opinion is guided by actual costs. For example, if the cost of producing cigarettes did not include the cost imposed on others by their production or use, no economist would regard the assessment of cost as accurate. This is true of all production. To the extent a firm is able to externalize costs, the costs for antitrust purposes will be lower. If predation is signaled by below cost pricing, ironically, the firm that is most adept at externalizing its costs will be the less likely to be viewed as engaged in predatory pricing. In antitrust terms, it will also be viewed as the most efficient producer when, in reality, it may be the opposite. ${ }^{71}$

This is not hypothetical. Firms in less developed countries or in states with relatively lax environmental laws, have lower private production costs. Similarly, more hazardous working conditions will lower internalized costs. In either case, that firm will be more likely to escape a claim of predatory pricing. We may or may not want those firms to produce. Perhaps the conditions for the workers in the firms involved are better than those that can be found elsewhere. On the other hand, when the merits of allocative efficiency are discussed, the fact that it may entail finding the neediest providers of inputs and exploiting them to the fullest, is rarely, if ever, discussed. In fact, a question that needs considered is whether antitrust policy should create incentives to find labor markets where working conditions are the poorest. Perhaps the answer is yes, but socio-economics provides a way to pierce the notion of efficiency and to expose the "cost" of always seeking to lower costs.

Some may doubt that an antitrust enforcement agency or a court could consider output markets. It may surprise readers to discover that they do already. When sellers have few options with respect to buyers,

69. 509 U.S. at 231.

70. Id.

71. No doubt the case will be made by some that producers ultimately internalize these costs as those negatively affected recover for the harm caused through the legal system. There may be some level at which this takes place but only the most ardent "true believer" would expect all costs to be internalized. 
those buyers have monopsony power. ${ }^{72}$ Antitrust law can be applied to monopsony much as it is applied to monopolists. ${ }^{73}$ Socio-economics allows, in fact demands, that the question to be asked is whether antitrust should value "allocative efficiency" when it is strictly a function of market power in output markets.

If markets did work, and free riding was eliminated, the issue of working conditions and preferences about the value of efficiency could be expressed in the demand curve. In fact, advertising for "fair-market coffee" and products made in America reflect preferences for those who supply inputs and their compensation. The free-rider problem arises when people reason, "I am for better incomes for coffee growers, and I want others to buy the higher priced coffee, but I will continue to buy the lower cost coffee." When enough people act on these preferences, the demand is not manifested in the market. Perhaps all of them would also say, "I will pay for this if others do," It is, thus, wishful thinking that "voluntary" market transactions tell us much about preferences and actual consumer surplus. In fact, emergence of markets for "fairness" are powerful indicators that antitrust goals are unnecessarily underinclusive.

\section{CONCLUSION}

As noted at the outset, the primary function of socio-economics is to ask questions and broaden the discussion. I have attempted to do that by unpacking and contextualizing the two economic goals of antitrust law-maximizing consumer surplus and allocative efficiency. I also have attempted to avoid what I believe is today's faith-based approach, exemplified by the Supreme Court. That approach has now gone beyond economics and seems to reveal, in its most benign form, a deep distrust of government.

At its most basic and obvious level, the two antitrust goals cede to those with income - earned or not-the right to determine how scarce resources are used. That may be fine in many respects and may be far superior to any other method. The problem is that consumer surplus is under-inclusive, recognizes only a small universe of values, and falls well short of measuring actual well-being. When the focus is on allocative efficiency and costs of production, antitrust courts and

72. A monopsony is a single buyer as opposed to a monopolist, which is a single seller in a market.

73. See Weyerhaeuser Co. v. Ross-Simmons Hardwood Lumber Co., 549 U.S. 312, 325 (2007). 
enforcement agencies are unlikely to recognize all costs and can perpetuate a race to exploit. To the extent the race to exploit is repugnant to some, they may be able to express that in markets but only to a limited extent.

The best way to sum up these comments is to begin with a quote from the leading antitrust scholar Herb Hovenkamp. He writes:

Determining which values maximize wealth is necessarily a question of determining what consumers will pay to have. Therefore, when Congress has not indicated otherwise, antitrust law should use consumer behavior in the voluntary marketplace as its principal source of policy. There, values are relatively clear: consumers almost always want low prices, high quality, and convenience of distribution. They may want and be willing to pay for other things, but they almost always want these things. In cases of doubt, it is a reasonable supposition that consumer welfare is maximized by offering consumers the best quality at the lowest price. ${ }^{74}$

One's first impression is: How could anyone disagree? Consumers do want quality and low prices. On the other hand, socio-economics has the capacity to question every express or implied assumption in this passage. What is a voluntary market? Is consumer surplus really maximized in markets based on predictions? What is the connection between wealth maximization and actual welfare? Are there instances in which consumers do not want low or the lowest prices? How is quality defined? Does it matter that high quality, to some, may involve values and motives that are socially undesirable? And, most importantly, is this the best antitrust law can do? Probably not, and those who protect the status quo without question may be the Luddites of antitrust scholarship.

74. Hovenkamp, supra note 12 , at 31 . 